\title{
Communication Pattern in Delivery of Messages in Crop Farming in West Muna Regency
}

\author{
La Tarifu ${ }^{1}$, Weka Widayati ${ }^{2}$, Bahtiar $^{3}$, Dasmin Sidu ${ }^{4}$ \\ ${ }^{1,3}$ Faculty of Social and Political Sciences, Halu Oleo University, Indonesia \\ ${ }^{2}$ Faculty of Sciences and Earth Technology, Halu Oleo University, Indonesia \\ ${ }^{4}$ Faculty of Agriculture, Halu Oleo University, Indonesia
}

\begin{abstract}
The goal of this research is to understand the communication pattern in message delivery in crop farming in West Muna Regency, Province of Southeast Sulawesi. The data analysis technique used in this research is Qualitative Descriptive. The result of this research shows that: (1) Farmers in Lawa Raya District still using interpersonal communication patterns and the head of the family or the guardians/parents is the main communicator of the messages delivery processes about crop farming. Communication pattern that happened inside the family can be qualified as linear and interactive. The parents sometimes use militaristic style of communication (force) to give instructions to family members so that they can do their roles in crop farming. (2) Farmers in Tiworo Raya District is more heterogeneous because there are immigrants. The communication patterns tend to be more dynamic and flexible because openness can be seen in the farmer's community. The communication pattern in message delivery in crop farming often seen in a faceto-face communication because there are many communicator that have a role in delivering the messages about crop farming, such as more advance farmers coming from immigrants, opinion leaders that voluntarily giving instructions about farming, and the leaders of farmers community that have been educated by facilitator and spread the knowledge to other members of the farmers society, and the facilitators that educate farmers continuously. Other than that, the farmers are now starting to understand and have awareness to search information alone on internet for the information they need. Therefore the communication pattern in message delivery about crop farming can be done simultaneously, whether it's in family, to other farmers, opinion leader, facilitators, as well as can be done with various communication media.
\end{abstract}

Keywords: Communication Pattern, Message Delivery, Crop Farming

\section{Introduction}

Natural resources of West Muna Regency is very strategic for the development in agricultural sector especially in crops farming. A very fertile soil and adequate labor can be possibly enhance the speed of development in agricultural sector rapidly. Generally the farmers in West Muna (Tiworo Raya) are already well-developed because supported by the existence of immigrants farmers that show them how to farm modernly and as well as having wetlands. Even so, in certain areas like Lawa Raya and Kusambi, there are no signs of advancement that can be found in Tiworo Raya. There are still many farmers that farms for themselves and their families only (subsistence), because the lands there are drier compared to Tiworo Raya. Farmers are generally have lowincome. The community there are quite homogeneous, not heterogeneous like in Tiworo Raya. The farmers there that use modern farming technology are mostly immigrants (Java, Bali, and Bugis), and a little part of locals that have adopted to the modern way of farming that they learned from the immigrants.

The development of farmers Tiworo Raya cannot be separated from the contribution of immigrants in delivering messages about how to farm better to the local farmers. The interactions between locals and immigrants also cannot be denied that it is exist. This means that it will have implication on culture diffusion on the farming system. Local farmers are doing new innovations in farming because there are intensive interactions with immigrant farmers that have the knowledge and skills in farming. Other than that, the local farmers are also supported by the opinion leader from the immigrant farmers' group, in which that they help deliver messages about how to farm better. The presence of facilitators that help to facilitate problems that are faced by the farmers are also helping agricultural sector in West Muna to grow even more. How the communication pattern in delivering messages of crop farming in West Muna Regency?

To find the communication pattern in delivering messages of crop farming in West Muna Regency. The result of this research hopefully beneficial in these terms: (1) Theoretically the result of this research can be a reference for institutions and other parties that works in related field; (2) Practically the result of this research can be used as considerations for policy-making in agricultural sector in West Muna Regency.

\section{Literature Review}

\section{Social Exchange Theory}

A relevant theory that can be used as an approach for this research is the social exchange theory and the Communicator Credibility theory. The Social Exchange theory sees interpersonal relations as a transaction like those in trading. People make relationships with others because they expect something back that can fulfill their needs. Thibault and Kelly concludes about the Social Exchange Theory:

Every individuals are voluntarily involve themselves and stay on the social relationships only if the relationship give them satisfaction that is seen from cost-benefit perspective. 


\section{International Journal of Science and Research (IJSR) \\ ISSN (Online): 2319-7064}

Index Copernicus Value (2013): 6.14 | Impact Factor (2015): 6.391

Benefit means something that have positive value as a result of involving oneself to the relationship (Rohim,2009).

Benefit in that perspective is something that holds positive value as a result of exchanging in the social system. While this research use Social Exchange Theory, the problem in this research can also be approached with Commucator Credibility Theory.

\section{Communicator Credibility Theory}

The main assumption in the credibility theory is that someone may be easier to persuade if the source of persuasion is credible enough. We often more believe and tend to accept well messages that delivered from someone experts and have credibility in his/her field. "High credibility sources had a substantially greater immediate effect on the audience's opinions than low credibility sources" (Hovland, 2007). Sources with high credibility have big impact on audience's opinion compared to sources that have low credibility. Sources with high credibility often results in a more significant behavioral change compared to sources that have low credibility. "When acceptance is sought by using arguments in support of the advocated view, the perceived expertness and trustworthiness or the communicator may determine the credence given them 'Hovland, (2007).

Communicator skills is the impressions that are constructed by communicant about how good the communicator is in his/her field in terms of what the context he/she talking about. A communicator that is highly regarded by the communicant as a skilled one is considered clever, able, adept, expert, experienced, and trained. Trust from the communicant, impressions, honesty, wise, sincere and just, objective, have integrity, and high social responsibility, Venus, (2009).

Effectivity in communication is not only determined by communication skills, but also supported by the personality of the communicator as well. Communication activity will runs well depending on the communicator if he/she have the ability to deliver messages or information to the communicant, in which, able to informs the communicant with new knowledge even changing their opinion until their behavior. Effendy (2003) said that communicator is someone or a group of people that deliver ideas into communication symbols that can be understand or accepted by communicant (Effendy, 2003). The relevance of the theory to the problem of this research is, that communicator factor is the source that delivers material in socialization which have criteria that involves credibility, trustworthiness, and attractiveness.

Credibility of the communicator is consists of expertise and trustworthiness. Meanwhile attractiveness of the communicator is all about similarity and familiarity, as well as liking and physical attractiveness, Tan, (2003). To conclude Tan's statement above, one can say that a communicator can be qualified as credible if the communicator have skills and trustworthiness from the communicant. Other than that, more factors that can support the success of communication is to have attractiveness. Next, skill is "impression that is constructed by the communicator on his/her skills that relevant with the topic or materials he/she talked about".

Rahmat, (2001) said that a communicator can be qualified as a high-skilled if the communicator able to deliver ideas or their minds that transformed into a message. You can see if the source is credible and someone who is expert on his/her field, you will give attention to the message more compared to those coming from a less credible source that also have less knowledge about the topic.

\section{Communication Pattern}

Syaiful Bahri Djamarah, (2004) says that communication pattern can be understand as a relation pattern between two or more people in the process of sending and receiving messages in the right way to makes the messages can be understand. There are two dimensions on communication pattern, first is the pattern that is concept-oriented and the second is the social-oriented one. Communication pattern is a process or a relation pattern that is done between two or more people to send messages between each other as intended. Communication pattern is a combination of two words; pattern and communication. Pattern in KBBI defined as form, system, or structure that is permanent. Pattern can be also defined as model, which can be defined as a way to show an object that contains complexity process and have relations between each processes that support it.

Tubbs and Moss (see Sunarto, 2000) say that communication pattern is characterized by the complementary or as a symmetric relationship. In complementary relationship, one dominant behavior from one participant incur others submissive behavior. In symmetrical relationship likability is the main factor on how far people will interact with each other. Dominance meet dominance, while submissive meets submissive, (Tubbs and Moss, 2001). In here we will start to see on how interaction process creates a system structure. How people respond each other determine the relationship type the have.

\section{Farming Concept}

The science of farming is the study about learning how one is able to work and coordinate production factors that is land and the nature itself as a capital or asset, to make full of its beneficial values. As a science, the science of farming help finds, organizes, and coordinates the usage of factors as effective and as efficient as it possible, which intended to gain highest profit as possible, (Suratiyah, 2000). The types of farming can be categorized from the type of the commodities, such as crops farming, horticulture, fisheries, animal husbandry, plantation, and forestry, (Suratiyah, 2008). Farming is an economic activity, in which economics plays it roles to develop it.

Farming is the ability of the farmers to organize and coordinate production factors that is managed as good as it can be. This means that farmers that is not have to much skills in utilizing crops, fertilizers, land size, labor, and pesticide will have lower income relatively (Yusri, 2005). To have an optimized land utilization by planting several commodities, farming plan is needed. Farming plan here is 


\section{International Journal of Science and Research (IJSR) \\ ISSN (Online): 2319-7064}

Index Copernicus Value (2013): 6.14 | Impact Factor (2015): 6.391

defined as the reorganization of farm resources by deciding goals, planning, creating programs by using limited resources.

\section{Crops Definition}

In the Bills of Republic of Indonesia Number 7 Year 1996, there are two known terms of food; food system and food security. Food system is defined as everything that is related with rules, guidance, and/or supervising in the activity of food productions and distributions until it is ready to be consumed by human. Meanwhile, food security is defined as the condition when food is fulfilled for each house that is reflected from the availability of the food stock, in terms of quantity and quality, safe, evenly distributed, and have reasonable/reachable price. In Indonesia, there are many crops type, such as (1) paddy, an ideal source of food that is very important for the people of Indonesia. (2) Corn, a commodity that is a good source of carbohydrate and can be served or processed in many ways. (3) Peanuts. Arachis hypogeae $L$ is a type of legumes that can be found cultivated in many areas of Indonesia. Peanuts is a plant that has overall height of 30 centimeters, (Anonim, 2014).

\section{Research Method}

This research is a descriptive research. Descriptive research is a type of research that is intended to describe phenomenons that exists, whether they are natural phenomenons or a human-made. Phenomenons can be in a form of activity, characteristics, changes, relations, similarity, and differences between one and other phenomenons (Sukmadinata, 2006:72).

This research focus on West Muna regency that consists of two study area characteristics, which are: (1) Farmer community that is homogeneous and still considered as traditional that domiciled in Lawa Raya (Lawa District, Wadaga, Saweridagi, and Barangaka). (2) Farmer community that is heterogeneous and pretty advanced that domiciled in Tiworo Raya (Central and South Tiworo District).

Informants are decided by purposive sampling technique by certain considerations and criteria. There are a total of 11 informants that consists of key informants and main informants. Key informants are consist of The Head of Crops and Horticulture Division, Head of BPP, and three facilitators that is corresponding with the numbers of districts in the regency. Meanwhile the main informants are decided to be six people, which are mainly the head of farmer groups as well as opinion leaders and other facilitators.

The Data Collection Technique in this research is by having observation and in-depth interview in informants that has been chosen before, that supported by detailed field data and recordings, which are intended to make the data originality, Mulyana, (2007).

Data analysis technique used in this research is the descriptive data analysis technique, via Miles and Huberman's interactive analysis technique that consists of three plot processes that happens simultaneously, which is data reductions, data display, and conclusion drawing/verification (Miles and Huberman, 1992:19-21).

\section{Results and Discussion}

Communication Pattern in Homogeneous Farmer Community

The communication pattern in delivering messages about crops farming in this study are spearated into two characteristics of the farmer's community, which are: (1) Homogeneous farmer's community (2) and heterogeneous farmer's community that based on their domicile. Communication pattern that happens in both characteristic of farmer's community have differences in how they farm. In the homogeneous community, it is often found that parents are became the main source of information in talking about farming stuff. Research data shows that farmers always talk about farming to every member of their family. Parents become the main communicator in instructing family members. By creating small discussions inside the family and persuading them through the discussions to asks for their willing to be involved in farming. In certain contexts, parents sometimes found to be using militaristic/forcing way and becoming more assertive to all family members to be involved in farming. The communication pattern that happens between farmers can affect their habits in farming as well depending on their orientation in doing farming. Communication pattern in the homogeneous community are often found to be asking to opinion leader for specific farming issues, such as deciding which day that seems to be right to start their farming. For instance when they want to work the land and planting paddy and corns that is started after they done with Kasalasa Ceremony, and when the time to harvest come, they have Parika (Kasalasa and Parika is the local tongue of Muna), (Transcendental Communication).

The habits to ask information on opinion leaders as well as parents in farming issues is a communication pattern that is linear and interactive. Linear because the farmers need to listen to what the parents or opinion leaders said before starting their farming work. Communication pattern that can be seen as interactive is when the farmers are asking to the parents or opinion leaders to discuss about the days to start the farming. Those things are in line with the perspective that Edward T. Hall, in Mulyana (2007) propose, that communication is a mechanism to socialize culture norms horizontally to from community to community, or vertically from a generation to the next generation.

The communication pattern between family members in doing farming is a reflection of the existence of living interaction between family members, which is done via messages that delivered by the parents by giving suggestion, persuasion, and even commands, which are intended to make the family members understand the feeling and will of their parents in doing farming together. This goes in line with the perspective of Albert Bandura, in Rakhmat, (2001) about Social Learning theory that says people do certain behavior because of imitations and affirmations. The communication pattern that is seen in family such as when the parents ask the family members to voluntarily involve in farming works that the family is depending to, or when the parents need to be 


\section{International Journal of Science and Research (IJSR) \\ ISSN (Online): 2319-7064}

Index Copernicus Value (2013): 6.14 | Impact Factor (2015): 6.391

more assertive by giving suggestions to the family member, or even a commands to make sure the family members are involved in the farming. The communication pattern that happened between farmers are often in a form of face-to-face communication, naturally happened without any detailed strategical planning that requires high awareness to reach the goal of the communication.

\section{Communication Pattern in Heterogeneous Farmer Community}

The transmigration in Muna West Regency is the main contributing factor in the development of agricultural sector there. This is reasonable because the farming habits of the immigrants are quite advanced is mixing with the traditional ways of farming that local farmers have. It is supported also by the harmonious life of between the locals and the immigrants from Java and Bali. The research data shows that between locals and immigrants are living open to each other ever since the coming of the immigrants. The communication pattern and the communication event that happened between both is a form of human interaction to create a profitable condition for both parties, a win-win solution. This happened because the immigrants are intensively display their knowledge by joining local farmer groups that keeps them to interact more and more as well as blurring into one community in doing farming.

Communication pattern between farmers can be seen in each of the interactions happened in the farmer groups that shows sign that there is less and less culture barrier from time to time. This is the main reason that the farming in the West Muna specifically in Tiwora Raya have a huge growth. This also in line with what Schramm (Rohim, 2009) propose, in which he says, that between human that keep interacting, there are those that share information, and also there are those that share ideas and behavior. Merrill \& Lownstein (Rohim, 2009) say that in the interaction environment between human, adaptation is always happening, whether it is self, mind, or even the making of a symbol that holds common meaning.

The communication pattern which is effective can be seen to have a sign of a good interpersonal relationships. The failure in secondary communication happened if the messages we understand yet the relation between the parties are destructed. Every time we do communication, we are not only delivering messages, but deciding on how good our interpersonal relation with those we communicate to as well. In short, communication is not only deciding which content we will talk about, but the health of the relationship between those we communicate to as well. Only with a good interpersonal relationship, the spread of knowledge in farming through social interaction is then possible. Between the local and immigrant farmers, there is often found discussions that talk about how-to farm well, how to process the land in order to plant certain crops, the use of fertilizer, the use of anti-weed products, and the what crop rotation is, and etc. The discussions between local farmers and immigrant farmers, local farmers can learn the what the immigrants know and have been experiencing in farming, and this also applies for the immigrants; they will know what the locals know and have been experiencing so far in farming in their region.
With this, the local farmers now have more knowledge and experience in farming from the immigrants, whether on how to farm better, or other positive experiences the immigrants have. The existence of the immigrants is important here as they can be media for the local farmers to learn on how to farm through the interaction between fellow farmers. This have implications on the way the local thinks and their behavior as well. Immigrant farmers bring new habit on modern farming that is more advanced and new experience in the farming system. By seeing them working in the farm, the local can slowly follow their habits in farming, such as planting paddy, corns, and fruits and vegetables as well. This give impression that the presence of the immigrants give positive impact on changing the local farmers' habit on practicing farming to be relatively better, which compared to before the coming of the immigrants their production is relatively stagnate from time-to-time. The local farmers' habit in practicing farming better is a result of a new environment. If we relate it with the perspective of Venus, (2009), Azwar (2011), Rahmat (2001), that the immigrant farmers as a communicator gives good impression to the local farmers that they have more knowledge and experiences, and also seen as a sincere source of information, honest, wise, just, objective, have integrity, and have social responsibility as well. Communicators in the communication process will have success when they able to show what is it called as a source credibility, which means they are trusted by the communicant. Immigrants in West Muna show that there are messages that accepted by the communicant that are thought to be true as well as relevant with the reality. Trustworthiness for the communicant to the communicator is decided with the ability for the communicator in certain working field that shows whether or not he/she can be trusted.

The impression of local farmers to the social interactions can be seen in their awareness in which they realize that they can get new knowledge and information on farming by interacting with other farmers. This is important for farmers from both sides that the interaction they are having everyday may give them new information and knowledge on farming better. The presence of immigrants give positive impact on spreading the knowledge and skills to the local farmer in farming. If before the immigrants come the local farmers are only doing farming for self-sufficiency, not to be sold, planting paddy not in a rice field, planting corns without first plowing the field, didn't know how to fertilize as well as the importance of fence and guarding the field in nights, now those habits are changing through the observation of local farmers in seeing how the immigrants work. If we relate this with Cognitive Dissonance theory, we can correlate it by saying that the local get information by their sensory input, they able to sense (e.g see, hear) how the immigrants work in farm as the stimulus in their environment, then by giving meaning to the information they just get, and finally transform the information into behavior they applies in farming, Griffin, (2003).

Slowly after the locals and immigrants doing interactions they started to understand each other and start having similarity and common understanding in farming. Locals in their own culture, are now starting to change. The ceremonies they often have before the immigrants come, such as

\section{Volume 5 Issue 7, July 2016}




\section{International Journal of Science and Research (IJSR) \\ ISSN (Online): 2319-7064}

Index Copernicus Value (2013): 6.14 | Impact Factor (2015): 6.391

Kasalasa and Parika, are now starting to be forgotten. Before, they plant for their own, not intended to be sold, they don't plant corns in a track, they are not guarding their crops every nights, they only have two harvest times in a year, they don't plot peanuts first, and there are others habits that the locals have that are starting to vanish because they are left by the locals after seeing on how the immigrants farm. By interacting with the immigrants, local farmers now starting to left their own original habits. The changing process that happens in the local farmers in their way to farm feels to them to give more profit and beneficial. This correlates with the Social Exchange theory mentioned before. People do interactions and create relationships hoping they get what they deserve after choosing something to sacrifice as the cost. In short, the theory sees interactions as a trading process. Thibault and Kelly concludes that the social exchange theory sees that individuals are voluntarily involved and stay in a relationship only if that relationship is beneficial to them when they see it in a cost-benefit perspective. The benefit here means everything they get that have positive value in a relationship, Thibault and Kelly (see Rohim, 2009). Benefits in what Thibault and Kelly means can be correlated to what the local farmers get after they voluntarily involved in the community spaces of the immigrants by interacting and communicating with them is a benefit, or a positive impact. This can be possible to happen because there is interaction and communication pattern that keeps both parties satisfied in a way. The communication process in the society are formed naturally which helps to create such conditions that makes both parties happy. This also can be possible because there are no language barriers; both locals and immigrants use Bahasa, which helps them to understand each other betters, both verbally and non-verbally.

Interactions between locals in their daily life are rarely using local language, even with their own ethnic, especially for the youth. This makes it easier for the immigrants to start having a communication with the locals, and by using Bahasa as the main language makes it easier also for the interactions to run well, this tends to make each sides understand each other better and trigger assimilation and live harmoniously together. If we come and asks the immigrant farmers about how to farm better, generally they have they own principle, honesty, sincere, and social responsibility as a fellow farmer. This makes us believe them and also have sympathy to them. Until now, the farmers from Java tends to accept the suggestion that are given by their friends, because they are tend to be more dynamic in delivering messages in farming, such as the usage of pesticide, and how to collect information about selling the farming products. Principally, people that have closeness physically in a certain environment makes the interactions and communication between them tend to be more flexible and relaxed. This is inline with what Rogers said. As a humanistic psychologists, he states a hypothesis, which says that the main barrier in the feedback on interpersonal communication is the tendency to us to naturally judges, evaluates, agrees, or disagree with the message, Rogers, in Rakhmat (2001).

Rogers' perspective if we correlates with the phenomenon on what happening in the interactions between the locals and the immigrants shows that the acceptance of the suggestions coming from the immigrants is because it gives what the locals need (advancement in farming) as well as showing trustworthiness. Moreover, the way the messages delivered is also a factor, the more dynamic, flexible, and show passion, create the attraction to listens to the messages within the familiarity in the farmer groups.

\section{Communication Pattern of Facilitator}

Facilitator as the communication channel in delivering messages about how to farm better to farmer ideally should have a good relationship with the target farmers. In the communication studies, communication messages can be delivered successfully if we give attention to the relationship factor with the communicant. It will be quite hard to expect the messages to be delivered or even accepted from the very first time when there is no good relationship between the communicator and the communicant. A professional facilitator in doing his works and functions first have to know and understand the farmer community's characteristic in the area he/she works. Intensive communication, humanist, and natural is a start of the work of a facilitator, which means he/she has to know the condition of the characteristic of the community where he/she works. Author believes that the ability that the facilitators should have are managerial, good relationship building skills, and communication skills.

A professional facilitator is able to deliver and convince the socialization target, so that they (in this case farmers), wants to listen, pay attention, interested to accept it, and at the end of the day changing their behavior, which in this case, to change to a better way of farming that is more productive. A good relationship building skill is a must and should be done by the facilitator. Research data shows that facilitators are now working as they should. But in there is some findings that show a more advanced farmers from the immigrants is more dominant in delivering messages about farming to the farmers. There is even a finding that the facilitator sometimes learn and educated by the immigrant farmers. Those immigrant farmers are both advanced farmer and opinion leader as well that often intensively spread the knowledge on a better farming.

Even so, the existence of the facilitator cannot be denied to have a large portion of contribution in giving guidance to the farmers in seeking the solution for the problems the farmers need to face. Generally the farmers are getting motivated by the facilitators to create groups in order to make it easier to give guidance or educating them. Through the farmer groups, the facilitators have it easier to do their job by communicating with the leaders of the farmer groups in spreading the messages about better farming. Research founds that because there is lack of facilitators in number, facilitators cannot reach through all the farmers in a relatively short time. This condition makes the facilitators only able to do the counseling about standard procedure on farming to the group leaders only.

Facilitators believe it is more effective to use the leaders in order to trigger the diffusion process of the message to all the farmers in the group. This correlates with the perspective of Kusnadi (2011), Hawkins (2012), which they said that the

\section{Volume 5 Issue 7, July 2016}




\section{International Journal of Science and Research (IJSR) \\ ISSN (Online): 2319-7064}

Index Copernicus Value (2013): 6.14 | Impact Factor (2015): 6.391

socialization on farming is the effort to deliver information (message) that is related by the agricultural sector by the facilitator for the farmers alongside with their family members, directly or indirectly, which goal is to make sure they know, have the willing, and able to use the innovation of the recent newest farming technology. We facilitators often do socialization directly with the farmers as well as doing indirectly sometimes with medias like brochures, posters, and detailed descriptive information that goes with what the farmers need. This also in line with the perspective of Madikanto (1993), Van den Ban and Hawkins (1999), that the success of the socialization is affected by the learning process that is experienced throughout the socialization and done by the targets.

The communication pattern in socialization is often directly done, but can be done indirectly as well, by using telephone for example, so that there will be larger reach of the socialization that can be done when the facilitator don't have enough time, for example. This communication pattern can reach targets in a quite large amount. If we see this from the side on how the information delivered, it is pretty good but there may be some limitations as it can only trigger awareness and fulfill sheer curiosity only. This is caused by the selective media use of both communicator and communicant, which may increase distortions and obstacles. Van den Ban and Hawkins, (1999) states that the communication pattern method for mass approach can be a general conference, radio broadcast, campaign, film screening, leaflet, poster, or folder, newspaper and etc. As a facilitator in farming issues, the facilitators are required to pay attention to the problems that the farmers face as well as their daily life that is in their working area.

\section{Conclusion}

Communication pattern in delivering messages about crops farming can be concluded into: (1) farmers that domiciled in Lawa Raya district still implements the interpersonal communication patterns, and the head of the family is the main communicator in the process of delivering farmingrelated messages. The communication pattern that happens in the family is linear and interactive. (2) farmers that domiciled in Tiworo Raya which is more heterogeneous because there is transmigration there have the communication patterns which are more dynamic and flexible because there community there is open to new things, especially the farmers in the farmer groups.

The communication patterns to deliver farming-related messages are done directly is more than those done indirectly because the communicators that have the roles for delivering the messages, such as immigrant farmers, opinion leaders, are giving the messages on better farming voluntarily, and the leader of the local farmer groups are spreading the knowledge they get from facilitator to the members of their own farmer group, and the facilitator also help by giving guidance to the farmers. Other than that, the farmers are starting to understand and have awareness towards searching information through the internet about everything that they need. By this, the communication pattern in delivering crops farming is done simultaneously, whether it is in the family, with other fellow farmers, by opinion leaders, facilitators, and as well as using other communication media.

\section{References}

[1] Adiwilaga, 1982. Farming Sciences. Publisher Alumni Bandung.

[2] Al-Rousan, M. Ramzi dan Badaruddin, Mohamed. 2010. "Costumer Loyalty and The Impact of Service Quality : The Case of Five Star Hotels in Jordan".

[3] Berlo, D. K. 1960. The Process of Communication Holt Rinehart and Winston Inc. New York.

[4] Cangara, Hafied. 2004. Introduction to Communication Studies. Raja Grafindo Persada, Jakarta.

[5] Daowei Sun and Ockie Bosch (2014) "Systems Approaches Towards Understanding the Barriers to Innovation Adoption in the Australian Beef Industry". The University of Adelaide Business School, Adelaide, SA 5005 Australia.

[6] Djamarah, B. S. 2004. Communication Patterns of Parents and Children in the Family. Jakarta: PT. Reneka Cipta.

[7] Efendy Onong,2000, Theory and Philosophy of Communication Sciences. Citra Adytiya Bakti, Bandung,

[8] Indraningsih, Kurnia Suci, (2011). Effect of Extension Decision Against Farmer Adoption of Integrated Farming Technology Innovation. Agro Economic Journal, Vol. 29 No. 1, pp.1-24.

[9] International Journal of Human and Social Science. Hal 886-892.

[10]Littlejohn, S.W. 1996. Theories of Human Communication. California: Wadsworth Publishing Company.

[11] Mulyana, Deddy. 2001. An Introduction to Communication Studies, Bandung, PT. Remaja Rosdakarya.

[12] Rahmat, J. 2000. Psychology of Communication. PT. Remaja Rosdakarya, Bandung.

[13]Rogers, E.M. \& Shoemaker, F.F., 1971, Communication of Innovations, London: The Free Press.

[14]Rohim, Syaiful, 2009. Communication Theory: Perspective, Variety \& Applications, Jakarta, Rineka Cipta

[15] Susanto, A.,. 1982. Contemporary Communications. Bandung, Bina Cipta.

[16] Tubbs, L Stewart dan Moss Sylvia. 2001. Human Comunication (konteks-konteks komunikasi). Bandung: Remaja Rosda karya.

[17] Venus, A, 2009 Free campaign management theoretical and practical in Campaign Streamline Communications. Sembiosa Rekatama Bandung

[18] report 200001, Indian Institute of Technology, Kanpur, India, 2000. (technical report style)

[19]J. Geralds, "Sega Ends Production of Dreamcast," vnunet.com, para. 2, Jan. 31, 2001. [Online]. Available: http://nl1.vnunet.com/news/1116995. [Accessed: Sept. 12, 2004]. (General Internet site) 